\title{
Surgical Sutures: The Necessary Update of Current Knowledge
}

\author{
Irami Araújo-Neto ${ }^{1}$, Maria Helena Wanderley Costa Dantas ${ }^{2}$, Tarciso Bruno Montenegro Sampaio ${ }^{3}$, Amália \\ Cinthia Meneses do Rêgo ${ }^{4}$ and Irami Araújo-Filho ${ }^{5 *}$ \\ ${ }^{1}$ Undergraduate Student of the Medicine Course, Potiguar University (UnP)-Laureate International Universities-School of Health, Brazil \\ ${ }^{2}$ Undergraduate Student of Nutrition Course, Potiguar University (UnP)-Laureate International Universities - School of Health, Brazil \\ ${ }^{3}$ Adjunct Professor, Department of Biology, Potiguar University (UnP)-Laureate International Universities - School of Health, Brazil \\ ${ }^{4}$ Post Graduation Program in Biotechnology, Potiguar University (UnP)-Laureate International Universities - School of Health, Brazil \\ ${ }^{5}$ Full Professor of the Post Graduate Program in Biotechnology at Potiguar University-Laureate International Universities, Brazil
}

Received: January 11, 2018; Published: February 13, 2018

*Corresponding author: Irami Araújo Filho, Full Professor of the Post Graduate Program in Biotechnology at Potiguar University-Laureate International Universities, Department of Surgery, Federal University of Rio Grande do Norte, Natal, Rio Grande do Norte, Brazil, Tel: +55 84 988760206; Email: irami.filho@uol.com.br

Abstract

Objective: To describe the physical characteristicsandbiological of thewires ofmoresuture usedinsurgical practice daily andtheir indications.

Methods: Review was conducted of literature through to search in the databases Pubmed, Embase, Web of Science and Scopus.

Results: Were described data on the qualities of the ideal suture, general classification and descriptive, criteria for use and the physical and biological characteristics of absorbable sutures, wires, monofilaments and multifilamentary.

Conclusion: It was possible to synthesizethecurrent knowledgetherespectofstrands ofsuture,to be used by students of medicine, surgery residents, surgeons and its subspecialties.

Keywords: Sutures; Sutures materials; Polymers; Suture; Absorbable effect; Non-absorbable effect suture; Biocompatible materials

\section{Introduction}

The suture thread began to be used for closing wounds 3.500 years before Christ in Egypt [1] and to this day the act of stitch is still the most common method for rapprochement of the edges of the surgical wounds. The suture material selection should be based on the biological properties of the tissues to be approximated, in the physical and biological characteristics of yarns and wound conditions to be closed. Even with the current advance of technology, it remains true that no suture has all the features that classify as the ideal wire.

\section{Qualities of the ideal suture}

a. Appropriate resistance.

b. Minimaltissue reaction.

c. Do not degrade intotoxic products.

d. Not facilitate the infection and remain stable in yourpresence. e. Arms andconstant resistance.

f. Coefficient of frictionfit.

g. Ability to maintain the resistance until whenneeded.

h. Absorption speed unaffected bybody fluids.

i. Be easy to handle-easy knot andfirm.

j. Appropriate elasticity

k. Not be changed with thesterilization.

l. Have lowpenetration.

m. Non allergenic and non-mutagenic.

n. Be lowcost.

\section{Objective}

Describe the physical and biological characteristics of the sutures used in surgical practice daily and their indications. 


\section{Methods}

Literature review was performed by searching in the databases Pubmed, Embase, Web of Science and Scopus on the topic, using the following keywords: sutures, sutures materials, polymers, suture, absorbable effect, non-absorbable effect suture, biocompatible materials. Were described data on the qualities of the ideal suture, general classification and descriptive, criteria for use and the physical and biological characteristics of absorbable sutures, wires, monofilaments and multifilamentary.

\section{Results and Discussion}

The suture can be classified according to several parameters that relate to your source material, structure and permanencein the tissues. So, as the degradation that they suffer in vivo are classified into two broad categories as absorbable and nonabsorbable sutures, both with wires that are manufactured from natural fibersor synthetic materials. Although the natural fiber yarns have been used for a long time and to this day are with good results, themost modern synthetic yarns are considered more suitable. Among other reasons, by the lower tissue reaction when compared to natural or organic yarn [2]. The sutures may also be characterized by your physical setup. Those consisting of a single filament are said monofilaments and the formed by multiple fibers, braided or twisted, are called multifilamentary. The nylon and the steel are examples of yarns available both as monofilaments and multifilamentary.

The general classification of the suture can be seen below, where trade names have been added to some of them, with the sole purpose of facilitating the identification of the same. The decision of using absorbable, monofilament or multifilament, not absorbable depends of a series off actors. There is that if you consider the time needed for the wound to heal, the voltage supported by tissue during the healing process and the issue of temporary or permanent need of the suture to ensure mechanical support. Experimental studies have revealed that the wires of suture in wounds of abdominal wall stopped to engage mechanical support between the days 15 and 28 of the postoperative period [3], and that only $41 \%$ of aponeurosis regained your initial resistance 2 months after being sutured [4]. Both findings like these, as the complex dynamics of muscle structures and aponeurotic of the abdominal wall and your susceptibility to incisions hernias and event, have provoked discussion about the choice of the best suture thread beingused.

The variations in the behavior of the different types of suture materials have been widely studied in vivo, in vitro, experimentally and clinically, each study emphasizing the qualities of each one of them. In general, the monofilaments are appointed as more advantageous, because the multifilamentary provide conditions for the development of infection, since bacterial colonies are formed in spaces between filaments $[5,6]$. Absorbable natural yarns (catgut) are responsible for the most intense inflammatory reaction among all suture, besides presenting a time very short and unpredictable absorption.

The emergence of the synthetic absorbable was very promising for several reasons:

a. Trigger inflammatory reactions significantly smaller than natural absorbable

b. Keep much of your resistance until the absorption process begins and if complete

c. Are available withtimes ofabsorption short,mediumandlong,givingopportunitytothesurgeon choose the suitable wire for each case

d. Quality mechanics of us isthe same for all the wirestested synthetic absorbable [4-6]. The description of each suture is made below.

\section{Absorbable}

\section{Catgut}

Yarn made from collagen extracted from the submucosa of the small intestine of sheep or cattle intestinal serosa, is available in the form of catgut simple and catgut chrome. The simple loses half of strength after 5 to 7 days in the tissues and $100 \%$ after 3 to 4 weeks. The treatment with chrome wire extends absorption and increases your resistance to stress. The catgut chrome loses $50 \%$ of the resistance in the 20 days 19 and $100 \%$ after 5 weeks in the tissues. It is a monofilament wire, absorbed by the mechanism of enzymatic digestion, which causes tissue significantly more intense reaction than the synthetic absorbable [7]. Should be avoided in suturing of tendons and fasciae, since they are healing slowly, structures that are subjected to efforts and constant tensions. In addition, the time of absorption of catgut is unpredictable. Is contraindicated in bleeding duodenal ulcers sutures or perforated, pancreaticojejunal anastomosis and biliary anastomosis, because it can be quickly disintegrated by the action of proteolytic enzymes [8].

\section{Polyglycolic Acid (Dexon)}

Multifilament yarn, braided synthetic absorbable by hydrolysis, in which is released the monomer glycolic acid soluble. It has been shown experimentally that the polyglycolic acid loses your strength after 28 days altogether in the tissues and is $100 \%$ absorbed within 60 days. As for postoperative adhesions, in the form of gel can reduce the formation of pericardial adhesions $[9,10]$. Clinical study showed that the closure of abdominal wall with Polyglycolic Acid resulted in $16 \%$ of infection, significantly higher than the $7 \%$ of infection that occurred when the wounds were closed with absorbable monofilament synthetic [11].

\section{Polyglactin 910 (Vicryl)}

Multifilament consists of $90 \%$ to $10 \%$ glycolic acid and lactic acid. About $50 \%$ of the yarn is absorbed by hydrolysis after the 28th day after surgery and $100 \%$ after the 70 th day [12]. When 
compared with the polidioxanona (PDS) in intradermal suture on the presence of erythema, induration, hypertrophic scarring and infection, there was no significant difference [13]. Used in experimental rabbits, pyeloplasty, proved to be the most suitable wire compared to other natural and synthetic resorbable wires [14]. Suture materials interact with immunocompetent cells and may affect host immunity. In experimental work was studied the influence of soluble factors of multiple sutures on the function of macrophages. It was found that your capacity for phagocytosis, adherence, lysozyme and production of tumor necrosis factor was significantly more affected by polyglactin, in comparison with the other wires [15].

\section{Polydioxanone (PDS)}

Monofilament yarn produced from the polymerization of paradioxanone. Of violet color, absorbed by hydrolysis, your time of absorption is more extended than polyglactin. Study in rats showed that the polidioxanone was present in vascular anastomoses after 120 days, suggesting that this material is safe invascular sutures [16]. On average, the absorption of the wire starts after 90 days and ends after 180 days. Anastomosis and micro anastomosis performed showed that the polidioxanone provoked little inflammatory reaction when compared with othermaterials of suture $[17,18]$. Study in vitro showed that the wires of suture release factors influencing behavior considerably immunotoxic macrophages and that these effects may have important clinical implications. One of the wires tested in the study, the polidioxanone and steel were the materials that have less inhibition of macrophage functions [15].

\section{Poliglecaprone (Monocril)}

Absorbable, monofilament is a copolymer of epsiloncaprolactone and glycoside. Laboratory tests have shown that shows excellent ease of handling, minimal resistance during passage through the tissues and resisting proper tension. The time of complete absorption between 90 and 120 days of deployment in the tissues, with minimal tissue reaction [19].

\section{Polyglyconate (Maxon)}

Slow absorption monofilament, features high resistance. Randomized clinical study showed that polyglyconate, even used with smaller diameter than the polyglycolic acid, retained high strength tension postoperatively, when employed in the closure of abdominal wall [20]. When it comes to sutured, presented infection rate significantly lower $(7 \%)$ on laparotomies lock, when compared with polyglycolic acid (16\%). Displays the node mechanically more secure than poliglecaprone and poliglactin [21]. Study conducted in rabbits, in which the femoral artery anastomoses were carried out under normal stress and increased showed, optical microscopy and electronics, that polyglyconate wire keeps the voltage resistance until complete healing of anastomosis. The tissue reaction proved to be minimal and the complete absorption was followed by total regeneration of the vascular wall, demonstrating that the cord is suitable for this type of fabric [21-23].

\section{Nonabsorbable Sutures}

\section{Cotton, linen and silk}

Are multifilamentares of natural fibers, yarns have high resistance, are easy to handle and provide firm mechanical node. His great virtue is the low cost, reason by which still today are widely used in many hospitals. For being multifilamentary of high capillarity, leverage infection more than monofilamentares wires nonabsorbable sutures. The intense inflammatory reaction causing decreases tissue resistance to infection and multifilament structure retains the bacteria in your intimacy. This facilitates wall infection, fistula formation and the elimination of through points of operative wounds. This way, these wires should be avoided in wound suture that present bacterial contamination. Silk, in particular, exerts a considerable inhibitory effect on the functions of macrophages, harming mostly the adhesion of these cells [15].

\section{Polyester (Dacron, Mersilene)}

Manufactured through polymerization resulting ester ethylene glycol combination with terephthalic acid, multifilament, braided, is of high resistance. By be a wire of high coefficient of friction, the handling is not of more easy, that makes your limited use. The us present unfavorable mechanical qualities, which made trying to improve quality coating your surface with teflon, silicone and polybutilate, targeting also decrease yourcapillarity. Polyester induces a significantly higher tissue reaction ofthe polypropylene in abdominal wound closure, with increased risk of infection [22]. The addition of inert materials and waterproof cover polyester filaments did not alter significantly the tissue inflammatory response, did not decrease the incidence of infection in contaminated wounds sewn up with this thread. Therefore, should be avoided in wounds with these characteristics.

\section{Polyamide (Nylon)}

Available as monofilament and multifilament, braided nylon causes little tissue reaction, can be used and is well tolerated in infected tissues in presentation monofilament. Is a low-cost, easy to handle, but we can dispose very easily. This requires the surgeon to make multiple nodes at each point of a suture, doing with that bacteria proliferate in the recesses of these nodes. Had once as chemically inert material, nylon decomposes over time in 1-6-hexanediamine and adipic acid, so that after 6 months in the tissue loses almost entirely your resistance to tension [23]. This loss is resistance by chemical degradation and not by physical phenomena as exhaustion of matter or undone the knots.

Proteolytic enzymes cause hydrolysis to attacking the amide group of the polymer, resulting in 1-6-hexanediamine and adipic acid. In vitro study indicateda probable antibacterial action of these degradation products of nylon, able to reduce the number of colonies of Staphylococcus aureusa concentrations varied [3]. However, when the wire was deployed in the subcutaneous tissue of rats for a prolonged period, their supposed degradation products did not show any antibacterial action [24]. 


\section{Polypropylene (Prolene, Surgilene)}

Monofilament wire, available in blue color, biologically inert even in the presence of infection. Is easy to handle, the node is firm, has proper elasticity and wide chemical resistance to acids, alkalis and enzymes. Its resistance to tension remained unchanged in tests conducted after several years of deployment in the tissues. Polypropylene has great tensile strength, although it can easily be fractured by the needles, as often occurs with the monofilamentares. Highresistance, combined with the appropriate elasticity, makes him a suitable wire for vascular anastomosis, anastomosis of tendons and suture of abdominal wall $[25,26]$.

\section{Polytetrafluoroethylene (PTFE)}

Is a non-absorbable monofilament wire, tested with good results in plastic surgery. In a comparative study with 10 other sutures, it was verified that the PTFE caused the less tissue reaction, making him considered the wire of choice for facial plastic surgery, where the critical functional and aesthetic results [27].

\section{Polybutester (Novafil)}

Monofilament non-absorbable synthetic which offers elasticity, flexibility and resistance to the voltage that the sensitive of the other of the same category. The degree of elongation at break time and safety of us are similar to those found in other sutures Nonabsorbable sutures, synthetic monofilamentares [28]. These features make it potentially beneficial for closure of the abdominal wall [29]. The wire has been tested on the skin of the abdominal wall to gauge the degree of hypertrophy and scar width, and the presence of transverse markings. The authors concluded that the polybutester decreases the risk of hypertrophic scar by own particular elasticity, which allows adaptation of the tissues the tension is exerted on them. When compared with the nylon, proved to be superior in all parameters studied [28]. In vascular anastomoses, the polybutester showed great ease of handling, knot tight, and most appropriate elasticity that polypropylene to monitor compliance of vessels [30].

\section{Steel (Aciflex)}

The relatively high infection rate found with the use of steel mono or multifilamentary can be the result of their physical and chemical characteristics. The steel is not as inert as the synthetic polymers. The metal can degrade through corrosion or by electrolysis, resulting in slow transfer of metallic ions to the tissues. Both the processes are very slow, but can be important in the etiology of surgical wound infection. Steel wires for being rigid, may cause considerable irritation tissues mechanics with operated movements, generating discomfort. So injured tissue may become susceptible to infection. Some studies report the use of collagen sponges impregnated with gentamicin for sternotomies sutures to prevent infection, without good results
[31]. The steel wire is high resistant and difficult to handle by the scant flexibility.

It is often used in sutures in mass of the abdominal wall, insternal closure, in the department of orthopedic surgery and in the hernia repair. Edlich et al. [26,32] conducted extensive collective review of literature showed the reliable performance of sutures of stainless steel monofilament under the following techniques of wound closure: sternal fixation, abdominal wound closure, inguinal hernia repair and closing skin wounds. Steel multifilament yarn has been used with good results in various types of suture of different organs.

McDonald et al. demonstrated that this wire ensured a secure attachment to a tendon, when compared to the Ethibond and Supramid sutures, showing minimum elongation of the multifilament and stainless steel better retention capacity of the node, resulting in a higher ultimate tensile strength in repairs of tendons $[27,33]$.

\section{Conclusion}

In conclusion, the existing knowledge of sutures and their biophysical chemistry characteristics contributes to the surgeons decide the proper use of these during surgical synthesis, contributing to best postoperative results, avoiding rejections, infections and other complications inherent to the operative procedure, favoring a speedy recovery of the patient with therapeutic costs reduction.

\section{References}

1. Snyder CC (1976) On the history of the suture. Plast Reconstr Surg 58(4): 401-406.

2. Dennis C, Sethu S, Nayak S, Mohan L, Morsi YY, et al. (2016) Suture materials-Current and emerging trends. J Biomed Mater Res A 104(6): 1544-1559.

3. Barros M, Gorgal R, Machado AP, Correia A, Montenegro N (2011) Surgical basic skills: surgical sutures. Acta Med Port 24 (Suppl 4): 1051-1056.

4. Zellner EM, Hedlund CS, Kraus KH, Burton AF, Kieves NR (2016) Comparison of tensile strength among simple interrupted, cruciate, intradermal, and subdermal suture patterns for incision closure in ex vivo canine skin specimens. J Am Vet Med Assoc 248(12): 1377-1382.

5. Hennessey DB, Carey E, Simms CK, Hanly A, Winter DC (2012) Torsion of monofilament and polyfilament sutures under tension decreases suture strength and increases risk of suture fracture. J Mech Behav Biomed Mater 12: 168-173.

6. Al Thunayan TA, Al Zahrani MT, Hakeem AA, Al Zahrani FM, Al Qattan MM (2016) A biomechanical study of pediatric flexor profundus tendon repair. Comparing the tensile strengths of 3 suture techniques. Saudi Med J 37(9): 957-962.

7. MacLean AB, MacLean SB (2008) Suture materials and subsequent wound strength. J Obstet Gynaecol 28(6): 561-562.

8. García Osogobio SM, Takahashi Monroy T, Velasco L, Gaxiola M, Sotres Vega A, et al. (2006) Single-layer colonic anastomoses using polyglyconate (Maxon) vs. two-layer anastomoses using chromic catgut and silk. Experimental study]. Rev Invest Clin 58(3): 198-203. 
9. Medeiros AC, Lima AD, Almeida AC (1990) 0 ácido poliglicólico implantado no subcutâneo de ratos como agente antibacteriano. Revista Saúde-UFRN 8: 22-25.

10. Yoshioka I, Saiki Y, Sakuma K, Iguchi A, Moriya T, et al. (2007) Bioabsorbable gelatin sheets latticed with polyglycolic acid can eliminate pericardial adhesion. Ann Thorac Surg 84(3): 864-870.

11. Chunder A, Devjee J, Khedun SM, Moodley J, Esterhuizen T (2012) A randomised controlled trial on suture materials for skin closure at caesarean section: Do wound infection rates differ? S Afr Med J 102(6 Pt 2): 374-376.

12. Rodeheaver GT, Thacker JG, Edlich RF (1981) Mechanical performance of polyglycolic acid and polyglactine 910 synthetic absorbable sutures. Surg Gynecol Obstet 153: 835-841.

13. Guyuron B, Vaughan C (1996) Comparison of polydioxanone and polyglactin 910 in intradermal repair. Plastic and Reconstructive Surgery 98(5): 817-820.

14. Wainstein M, Anderson J, Eoder JS (1997) Comparison of effects of suture materials on wound healing in a rabbit pyeloplasty model. Urology 49: 261-264.

15. Uff CR, Scott AD, Pockley AG, Phillips RK (1995) Influence of soluble suture factors on in vitro macrophage function. Biomaterials 16: 355360

16. Park JH, Song HY, Shin JH, Kim JH, Jun EJ, et al. (2014) Polydioxanone biodegradable stent placement in a canine urethral model: analysis of inflammatory reaction and biodegradation. J Vasc Interv Radiol 25(8) 1257-1264

17. Quesada D, Diago V, Redondo L (1995) Histologic effects of different suture materials in microsurgical anastomosis of the rat uterine horn. J Reprod Med 40: 579-584.

18. Pihlajamäki HK, Salminen ST, Tynninen O, Böstman OM, Laitinen O (2010) Tissue restoration after implantation of polyglycolide, polydioxanone, polylevolactide, and metallic pins in cortical bone: an experimental study in rabbits. Calcif Tissue Int 87(1): 90-98.

19. Bezvada RS, Jomilkowski DD, Lee LY (1995) Monocryl suture, a new ultra-pliable absorbable monofilament suture. Biomaterials 16: 11411148.

20. Trimbos JB, Niggebrugge A, Trimbos R, Van Rijssel EJ (1995) Knoting abilities of a new absorbable monofilament suture: poliglecaprone 25 (Monocryl). Eur J Surg 161: 319-322.

21. Thompson SR, Gregory MA, Mars M (1995) Morphological aspects of microarterial anastomosis: a comparison of nylon with polydiaxanone. Br J Plast Surg 48: 165-171.

This work is licensed under Creative

Commons Attribution 4.0 Licens

DOI: 10.19080/OAJS.2018.08.555730
22. Okada N, Oshima H, Narita Y, Usui A (2015) Nonanastomotic Rupture of a Woven Polyester Graft Caused by a Tacking Stitch After Aortic Arch Replacement. Ann Thorac Surg 100(6): 2370-2376.

23. Netscher DT, Badal JJ, Yang J, Kaufman Y, Alexander J, Noble P (2015) Biomechanical evaluation of double-strand (looped) and single-strand polyamide multifilament suture: influence of knot and suture size. Hand (N Y) 10(3): 417-424.

24. Medeiros AC, Pinto Jr FEL, Costa MGMA (1996) Efeitos antibacterianos dos produtos de degradação dos fios de nylon. Estudo experimental. Rev Ass Med RN 1: 8-10.

25. Nilsson T (1981) The relative importance of Vicryl and Prolene sutures in the strenght of healing abdominal wounds. Acta Chir Scand 147: 503-507.

26. O’Brain ES, Earley MJ, Smyth H, Hooper AC (1995) Absorbable sutures in tendon repair. A comparison of PDS with Prolene in rabbit tendon repair. J Hand Surg 20: 505-508.

27. Setzen G, Willams EF (1997) Tissue response to suture materials implanted subcutaneously in a rabbit model. Plast Reconstr Surg 100: 1788-1795.

28. Rodeheaver GT, Borzelleca DC, Thacker JG, Edlich RF (1987) Unique performance characteristics of Novafil. Surg Ginecol Obstet 164: 230236.

29. Rodeheaver GT, Nesbit WS, Edlich RF (1986) Novafil: A dynamic suture for wound closure. Ann Surg 204(2):193-199.

30. Megerman J, Hamilton G, Schmitz-Rixen T, Abbott WM (1993) Compliance of vascular anastomosis with polybutester and polypropylene sutures. J Vasc Surg 18: 827-834.

31. Godbole G, Pai V, Kolvekar S, Wilson AP (2012) Use of gentamicincollagen sponges in closure of sternal wounds in cardiothoracic surgery to reduce wound infections. Interact Cardiovasc Thorac Surg 14(4): 390-394.

32. Edlich RF, Drake DB, Rodeheaver GT, Winters KL, Greene JA, et al (2006) Syneture stainless STEEL suture. A collective review of its performance in surgical wound closure. J Long Term Eff Med Implants 16(1): 101-110

33. McDonald E, Gordon JA, Buckley JM, Gordon L (2011) Comparison of a new multifilament stainless steel suture with frequently used sutures for flexor tendon repair. J Hand Surg Am 36(6): 1028-1034.

\section{Your next submission with Juniper Publishers} will reach you the below assets

- Quality Editorial service

- Swift Peer Review

- Reprints availability

- E-prints Service

- Manuscript Podcast for convenient understanding

- Global attainment for your research

- Manuscript accessibility in different formats

( Pdf, E-pub, Full Text, Audio)

- Unceasing customer service

Track the below URL for one-step submission https://juniperpublishers.com/online-submission.php 